19

Effectiveness and Variability of Digestion Procedures for Zinc Determination in Aged, Contaminated Soils

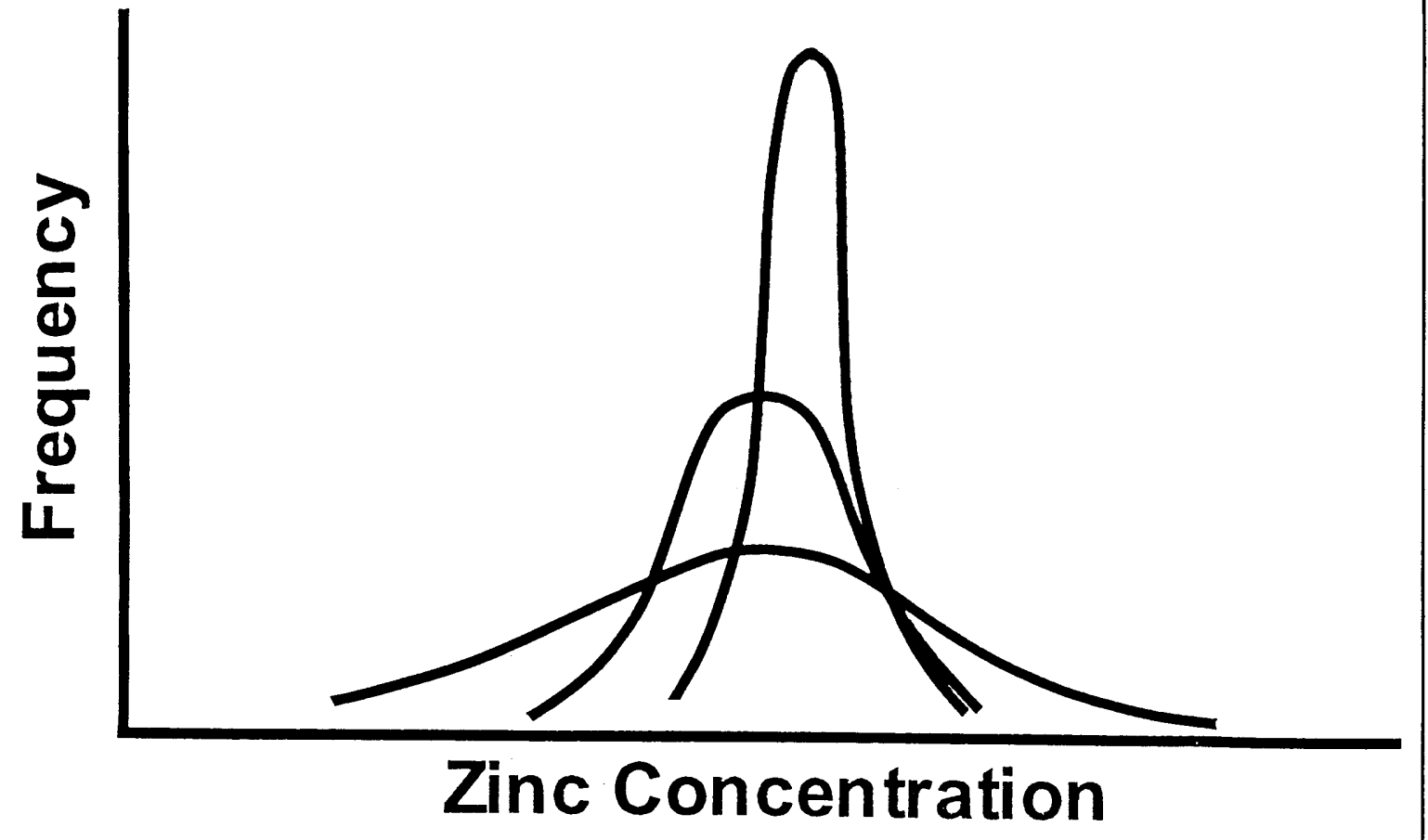




\begin{abstract}
Owing to the numerous advantages provided by microwave digestion, regulatory agencies are recognizing its value, yet most reported comparisons of microwave digestions with other accepted methods have used ores, laboratory-spiked soils, or soils with unexceptional, rather than elevated, metal concentrations. Objectives of this research included evaluating microwave digestion for routine laboratory use and comparing microwave, block digester, and hot-plate soil digestion techniques for determining zinc in aged, zinc-contaminated soils. Soil samples, chosen to provide a more realistic and rigorous test of the digestion procedures than would spike recovery methods and known to contain appreciable quantities of zinc, were collected from sites near a zinc smelter that had operated for more than 80 years. To obtain a range of zinc concentrations, surface $(0-20 \mathrm{~cm})$ samples of Weikert silt loam soil (loamy-skeletal, mixed, mesic, shallow Typic Dystrochrept) were collected from a location subject to airborne contamination from the smelter site. Very highly significant effects for digestion method, soil, and method $\times$ soil interaction were observed. Considering all the soils analyzed as a group, there was no significant difference in zinc release between two separate microwave digestions, or between the hot-plate and block digestion methods. However, microwave digestion resulted in significantly more complete metal release and greater metal concentration values than did either the hot-plate or block digestion methods. Effect of digestion method was not constant among soils. Uniformity for the microwave digestion replications was better than for either block or hot-plate methods. Incomplete digestion and contamination occurred more frequently using hot-plate digestion. For two separate but identical microwave digestion treatments, the average coefficient of variability (CV) values of digestion replication means were $20.5 \%$ and $28.7 \%$, respectively. The analogous values for the block digestion and hot-plate methods were $39.2 \%$ and $69.5 \%$, respectively. The hot-plate digestion variability was significantly greater than either the block digestion or microwave methods. Microwave digestions provided markedly faster digestion times and often greater zinc release than other methods. Zinc release using microwave digestions was equal to or greater than that using other methods. This study demonstrated that regardless of digestion method, variability within a soil sample presents significant challenges, both in obtaining uniform analytical results and in interpretation.
\end{abstract}

For conversion of SI metric units to U.S./British customary units of measurement consult ASTM Standard E380, Metric Practice Guide, published by the American Society for Testing and Materials, 1916 Race St., Philadelphia, Pa. 19103. 
CRREL Report 92-15

U.S. Army Corps

of Engineers

Cold Regions Research \& Engineering Laboratory

\section{Effectiveness and Variability of Digestion Procedures for Zinc \\ Determination in Aged, Contaminated Soils}

Charles M. Reynolds

and

OFFICE OF THE CHIEF OF ENGINEERS 


\section{PREFACE}

This report was prepared by Dr. Charles M. Reynolds, Research Physical Scientist, Geochemical Sciences Branch, Research Division, U.S. Army Cold Regions Research and Engineering Laboratory. Funding for this work was provided under Project R-90, Analytical Systems Support, by the U.S. Army Toxic and Hazardous Materials Agency (USATHAMA) (Durant Graves, Project Monitor) and DA Project 4A161102AT24, Research in Snow, Ice, and Frozen Ground, Work Units SS/020, Chemical Species Transport Phenomena in Snow and Frozen Ground.

This report was technically reviewed by Dr. Giles Marion, Dr. Thomas Jenkins, and James Cragin of the Cold Regions Research and Engineering Laboratory. In addition, Dr. Paul Mastradone, U.S. Environmental Protection Agency, provided technical review and consultation on portions of the report. Appreciation is extended to the reviewers for their thoughtful suggestions and comments. The author gratefully acknowledges the laboratory assistance of Lawrence Perry, Barbara Lajoie, and Dianne Reynolds in conducting the laboratory work and Alan Hewitt, for kindly supplying a microwave digestion apparatus. Lastly, sincere appreciation is extended to Dr. J.S. Angle, Department of Agronomy, University of Maryland, for graciously providing soil samples that met the requirements of this study.

The contents of this report are not to be used for advertising or promotional purposes. Citation of brand names does not constitute an official endorsement or approval of the use of such commercial products. 


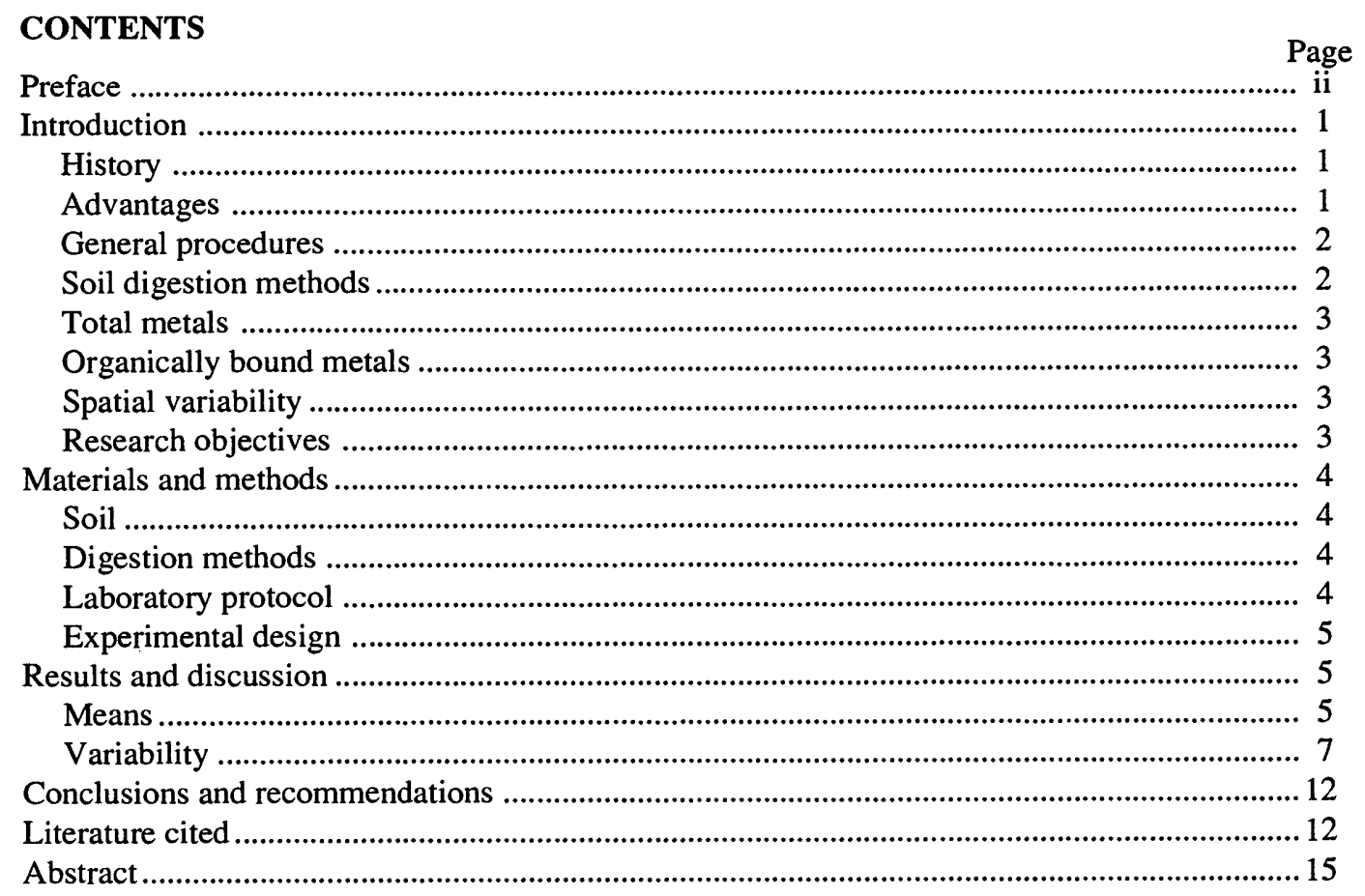

\section{TABLES}

Table

1. Results of two-way ANOVA for randomized complete block design for all data blocked on replicates

2. Duncan's multiple range test for comparing zinc levels in soils, using means of digestion methods at the 0.01 significance level

3. Duncan's multiple range test for comparing effects of digestion method among means of all soils at the 0.01 significance level......

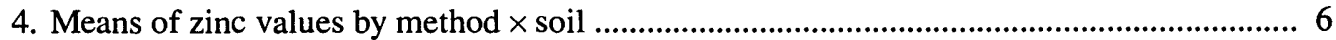

5. Summary of ANOVA by soil, significance of digestion method, and blocking effects on zinc release ..............................................................................................................6 6

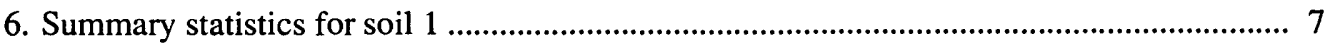

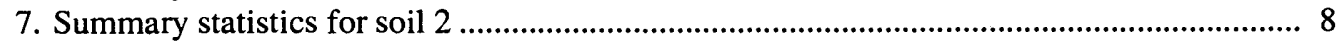

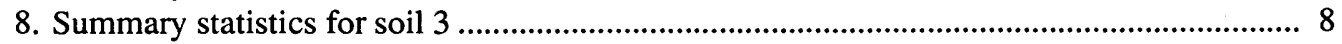

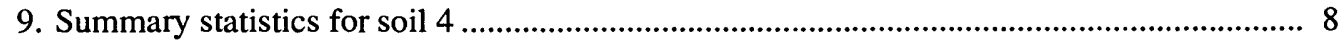

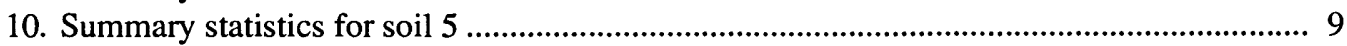

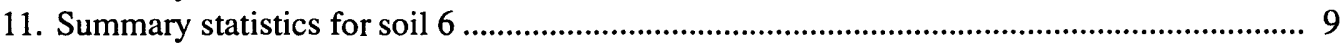

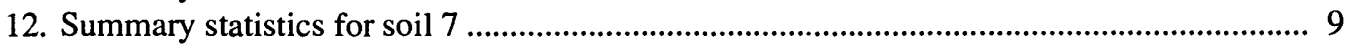

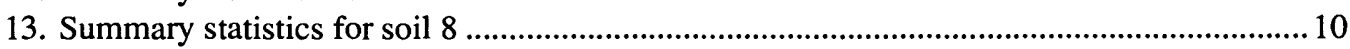

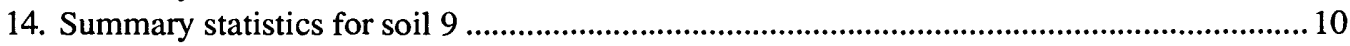

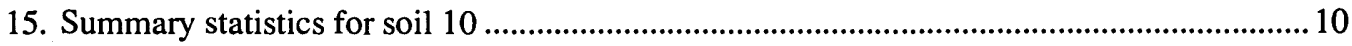

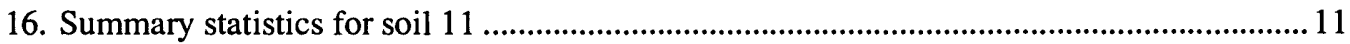

17. Summary statistics for soil 12 ............................................................................... 11

18. Results of Duncan's multiple range test for comparing digestion method variability, expressed as CV of replications, at the 0.01 level ............................................................. 11

19. Summary of results of one-way ANOVA for completely random design comparing variability, expressed as CV of replications, of digestion methods for 12 soil treatments ........... 12 


\title{
Effectiveness and Variability of Digestion Procedures for Zinc Determination in Aged, Contaminated Soils
}

\author{
CHARLES M. REYNOLDS
}

\section{INTRODUCTION}

\section{History}

Increasingly, microwave energy has been used as a heating source in acid dissolution and extraction of metals from soils and for the digestion of soil fractions prior to analysis for other constituents. Since the mid1980 s, there has been a marked increase in the number of papers describing microwave digestion methods. Many investigations have focused on the use of various digestion vessels, compared mineral acids for digesting different materials, and determined the suitability of techniques for quantifying specific analytes in standard reference materials. These searches have been driven by both the increased national concern for soil and ground water quality and the need for rapid sample preparation methods to complement the markedly faster rate at which chemical analysis of solutions can be accomplished by modern instrumentation. As the result of joint research between the National Institute of Standards and Technology (NIST) and manufacturers of scientific instrumentation, a number of methods have been studied in detail (Kingston and Jassie 1986, 1988).

The availability of commercial microwave digestion systems, including ovens, vessels, and attendant equipment, has encouraged the development of microwave techniques and has further promoted efforts to standardize microwave methodologies (Kammin and Brandt 1989b, Lautenschlaeger 1989, Grillo 1990). Recently, the United States Environmental Protection Agency (USEPA) approved a closed-vessel microwave digestion procedure for use by laboratories participating in the USEPA Contract Laboratory Program (CLP) (Tatro $1990 \mathrm{~b}$ ). With these efforts, microwave techniques are in transition from a commonly used but unrecognized research tool to an acceptable and documented group of methods for routine use in analytical chemistry.

\section{Advantages}

As an energy source for heating digestion solutions, microwave energy has several advantages. Sulcek and
Povondra (1989) cite both the increase in efficiency in thermal energy transport using the $300 \mathrm{MHz}$ to $300 \mathrm{GHz}$ microwave spectrum, rather than the $50-$ to $300-\mathrm{Hz}$ spectrum used in electrical heating, and the reduced radiant heat loss as two advantages of microwave heating. Neas and Collins (1988) and Gilman and Grooms (1988) have attributed microwave heating to both ionic conduction and dipole rotation of the solution molecules; they discussed the changes in relative contributions of each mechanism as heating occurs in a sample. Nadkarni (1984) discussed possible mechanisms whereby internal heating of solutions may result in better acid-particle contact and therefore, more rapid and complete digestion. Fischer(1986) suggested the possibility of mechanical agitation and rupture occurring during heating. These events would expose more sample layers to the surface and subsequent acid attack, thereby increasing dissolution.

The net result of these advantages is a dramatic decrease in the amount of time needed for sample digestion. Depending on the medium, digestions that formerly took 2 to 3 days can be routinely completed in as little as 10 minutes, and digestions that formerly took hours can be done in several minutes (Borman 1986). Although microwave digestion results in faster digestion times, the actual mechanisms controlling the benefits that microwave heating may provide are not completely understood, and Kingston and Jassie (1988) caution against treating microwave digestion methods as simply another way to heat acid.

In addition to faster digestion times, other advantages frequently cited for microwave digestions are less contamination and improved recoveries. Closed vessels are obviously less prone to cross-contamination and contamination from aerosol sources, and closed-vessel blanks reflect this fact (Borman 1988). Moreover, the ability to use less acid in the digestion vessels, and therefore the blanks, results in low background levels of metals. Skelly and DiStephano (1988) used closedvessel microwave digestions to reduce aluminum (Al) levels in blanks from $10 \mu \mathrm{g} / \mathrm{kg}$ to $1 \mu \mathrm{g} / \mathrm{kg}$, which was 
sufficiently low to allow analysis of trace amounts of $\mathrm{Al}$ in samples.

Improved recoveries involve at least two factors: reduced losses of volatile analytes and higher temperatures and pressures within closed digestion vessels. It is well known and documented that the rate and efficiency of digestion increases with temperature, but in open vessels desirable increases in temperature must be tempered with losses of volatile analytes, evaporation of digestion acids, and the potential for explosion. Using open-vessel digestion, low recoveries of arsenic (As), boron $(\mathrm{B})$, chromium $(\mathrm{Cr})$, mercury $(\mathrm{Hg})$, antimony $(\mathrm{Sb})$, selenium $(\mathrm{Se})$, and tin ( $\mathrm{Sn}$ ) have been observed, and it is generally accepted that volatile losses are the cause (Borman 1986). Digestion completion is largely dependent on the subjective decisions of the analyst when open, hot-plate methods are used. By combining the effects of both increased temperature and pressure in closed vessels, relatively simple digestion solutions have been used successfully, and because evaporative losses of digestion acids are avoided, smaller volumes of acids are needed. These two factors also contribute to the reduction of background metal concentrations associated with digestion solutions.

\section{General procedures}

The need to calibrate any oven used for digestions requiring quantitative recovery is both important and generally recognized. Kingston and Jassie (1988) have given detailed information on monitoring and predicting conditions during microwave digestions. Because microwave heating occurs at exceedingly rapid rates, minor differences in digestion time can result in significant variability in the degree of digestion and the corresponding dissolution of metals into solution. This effect is most pronounced early in the digestion process, before reaching the portion of the metal release curve that is asymptotic to the total concentration value. One way to circumvent this problem is to use digestion times that are slightly longer than necessary, thereby allowing digestions to more fully approach completion. However, the appropriate amount of time is not well defined. Kammin and Brandt (1989a) found that microwave heating for 95 minutes resulted in a greater release of oxide-bound refractory elements such as $\mathrm{Al}$, vanadium (Va), and $\mathrm{Cr}$ compared with the amount released during a 15-minute microwave digestion. The complete dissolution of all forms of bound metals is not simple. Data show that dissolution does not proceed linearly with respect to digestion time, but the dissolution kinetics of recalcitrant species in a microwave field is relatively obscure.

For the practical use of closed-vessel microwave digestions, temperature and pressure are high. In some sit- uations, small increases in digestion duration can dramatically affect the degree of completion of metal dissolution. The detailed descriptions provided by Kingston and Jassie $(1986,1988)$ for microwave oven calibration are based on temperature increases in known masses of water and typical digestion acids. Compilations of methods for microwave digestion of different materials have also been published (Kingston and Jassie 1988). Nevertheless, most digestion schemes published have used empirically developed digestion times and microwave power settings that may not be transferable to other soils, digestion solutions, vessels, or microwave systems. Commercial microwave ovens developed for laboratory use have addressed this problem by monitoring the pressure within the digestion vessels and using real-time feedback to control the microwave power, thereby controlling conditions within the closed vessels (Gilman and Engelhart 1988).

Both open and closed vessels have been used for microwave digestions. At present, Teflon bombs appear optimum. Teflon is transparent to microwaves and allows rapid heating of the contents rather than the vessel. Consequently, using microwave heating allows digestion solutions to reach higher temperatures without harming the vessels than does heating by other methods (Gilman and Engelhart 1988). To assist in physically maintaining the pressures generated within closed digestion vessels, Teflon linings or inserts placed inside more rugged vessels have been developed; they generally include pressure relief and venting systems (Gilman and Engelhart 1988).

\section{Soil digestion methods}

A large number of protocols for the dissolution of metals from soils have been developed. Generally, soil dissolution methods use a mineral acid such as nitric, hydrochloric, or sulfuric acid and an oxidant such as perchloric acid, hydrogen peroxide, or heat to oxidize the organic fractions of the soil. Although many of these methods, with the exception of those using both hydrofluoric acid and a strong oxidant, were not developed to completely solubilize all metals in soil, they are frequently referred to as digestions for "total" metal content. Numerous investigators have reviewed the advantages of different mineral acids in bringing forms of metals into solution for analyses (Lim and Jackson 1982, Kingston and Jassie 1988, Sulcek and Povondra 1989). As an aid in choosing the appropriate protocol, computer-based expert systems for advice on sample preparation using microwave digestions are being developed (Settle et al. 1989, Borman 1990). Descriptors included in the expert system are analyte and expected concentration, type of matrix, and instrumental technique. 


\section{Total metals}

Many of the numerous reports on microwave digestion of soils and sediments that have been published since approximately 1983 have dealt with total metal content (Matthes et al. 1983, Nadkarni 1984, Lamothe et al. 1986). This is reflected in the frequency of comparisons of microwave digestion results with values established by the NIST. Depending on the metal in question, the matrix involved, and the objective of the study, a wide range of acids and oxidants can be used in microwave digestions. There is a quantity of published information on choices of different mineral acids for dissolution of different metal species in soils (Page et al. 1982, Sulcek and Povondra 1989). Methods recognized by regulatory agencies may not quantitatively recover all metals. The USEPA SW846, Method 3050, uses $\mathrm{HNO}_{3}, \mathrm{HCl}$, and $\mathrm{H}_{2} \mathrm{O}_{2}$ for digestion, and the recently announced microwave procedure, CLP 3/90 Statement of Work (SOW), uses only $\mathrm{HNO}_{3}$. Yet Kimbrough and Wakakuwa (1989) have demonstrated that using an initial digestion acid solution of $\mathrm{HNO}_{3}$ alone does not quantitatively recover antimony $(\mathrm{Sb})$ or silver $(\mathrm{Ag})$, and they have suggested using a $4: 1 \mathrm{HNO}_{3}: \mathrm{HCl}$ initial digestion solution to release these elements.

For many years it has been accepted that hydrofluoric acid (HF) is needed to release isomorphically substituted metals in the silicate lattice (Lim and Jackson 1982). Therefore HF has typically been used in evaluations of microwave digestion methods using NIST standard reference materials. In some instances, such as uncontaminated soil with negligible organic matter content, the portion of the metal that is held by isomorphic substitution and that therefore requires $\mathrm{HF}$ for release may be a substantial percentage of the total metal content. Generally, in contaminated soils, metals held by isomorphic substitution comprise only a small fraction of the total metal content in soil. When either anthropogenic or naturally occurring metal additions are made after mineral formation, the bulk of added metal remains in other forms such as oxide- or carbonate-bound, organically complexed, or held on exchange sites and does not enter the silicate lattice (Tessier et al. 1979). Consequently, as the degree of contamination increases, the percentage of the total metal content held by isomorphic substitution and requiring hydrofluoric acid for release becomes increasingly small. For quantifying most metals in contaminated soil, a relatively simple digestion appears sufficient.

\section{Organically bound metals}

Release of organically bound metals requires oxidation of the organic component of the soil; this is typically one of the more difficult problems in metal dissolutions. There are different opinions as to the importance of organic matter oxidation during digestion processes. The most complete oxidizing method is dry ashing, or combustion at $400^{\circ} \mathrm{C}$ for 30 minutes, yet this results in the volatilization of some elements. Tatro (1990a) summarized reports and concluded that $10-15 \%$ of the original organic carbon (C) remained after acid digestion using microwave energy. Because a large percentage of metal in soil can be organically bound, failure to quantitatively digest the organic fraction can increase analytical error.

Conversely, other reports have indicated that although many oxidizing acid digestions leave a residue in the digest, metal recoveries are not significantly different from more complete digestions (Nadkarni 1984, Smith and Cousins 1985, Nakashima et al. 1988). There are suggestions that, with time, anthropogenic additions of metals may become increasingly bound into forms more resistant to dissolution and subsequent analyses (Palazzo and Reynolds 1991). Although complete recovery of metals immediately following addition of metal to the soil can be accomplished by many digestion or extraction methods, it is important to realize that tests such as spike recoveries do not necessarily simulate recovery efficiencies for typical field samples.

\section{Spatial variability}

For many years it has been well documented that sampling comprises the greatest source of error in characterizing soils (Peterson and Calvin 1982). Using a compilation of various studies, Markert (1990) estimated that the relative errors associated with sampling can range up to $1000 \%$, while errors related to sample preparation ranged between 100 and $300 \%$. Instrumentassociated errors typically were only 2 to $20 \%$. Contaminant heterogeneity in soils is difficult and timeconsuming to assess. Because contaminated portions of a soil may exist as discrete portions on regional, macro, and micro scales, variability between or within samples can be significant. Geostatistical methods to evaluate soil data, design sampling strategies, and compensate for spatial variability in soil has been an area of intensive research in soil science for over 10 years (Warrick et al. 1982). Touse emerging methods optimally, increasingly large amounts of data are beneficial. Rapid sample preparation using microwave digestion techniques should be a valuable tool for efficient, inexpensive data acquisition and may increase our ability to identify underlying processes governing the fate of metals in soil and the hazards associated with them.

\section{Research objectives}

Currently, numerous pathways for metal transformations in soils are known; consequently, anthropogenic metals may occur in soils in many possible forms. 
Although availability and degree of hazard associated with soil metal concentrations are largely dependent on metal speciation, metal release following hot acid digestion is a criterion that regulatory agencies commonly use to determine metal levels in soils. Owing to the numerous advantages provided by microwave digestion, regulatory agencies are recognizing its value. Nevertheless, most reported comparisons of microwave digestions with other accepted methods have used ores, laboratory-spiked soils, or soils with unexceptional (rather than elevated) metal concentrations. Objectives of this research included evaluating the advantages and disadvantages of microwave digestion for routine laboratory determination of zinc and comparing the microwave digestion of aged, contaminated soils with more traditional and accepted digestion methods, with emphasis on delineating the sources of variability in sample analysis.

\section{MATERIALS AND METHODS}

\section{Soil}

To obtain a range of zinc concentrations, surface $(0$ $20 \mathrm{~cm}$ ) samples of Weikert silt loam soil (loamy-skeletal, mixed, mesic, shallow Typic Dystrochrept) were collected from locations subject to airborne contamination from a zinc smelter site. The soil samples were obtained in May 1990 and were known to contain appreciable quantities of zinc. The smelter had been in operation for more than 80 years, so the samples had been exposed to freeze-thaw and wet-dry cycles as well as other weathering and aging processes; samples from this site were chosen to provide a more realistic and rigorous test of the digestion procedures than would spike recovery methods. The samples were obtained in fieldmoist condition and stored at $4^{\circ} \mathrm{C}$. Prior to analysis they were air-dried, and each air-dried soil sample was mixed. Composite subsamples were taken for gravimetric moisture determination using oven drying overnight at $105^{\circ} \mathrm{C}$. Sample weights used for metal analysis were corrected for moisture content.

Obtaining a representative sample of a heterogeneous solid such as soil is difficult. A balance must be achieved among:

i) extensive sieving and mixing, with the attendant chance for introducing contamination or omitting larger aggregates,

ii) physical grinding, which may introduce contamination or unintentionally and differentially aid digestion completion by physically altering the soil particles, and

iii) extensive composite sampling, which relies on a number of random, composite subsam- ples to obtain a representative sample, although the effects of spatial variability inherent in an extremely heterogeneous matrix, such as contaminated soil, persist.

Because the objectives of this study included comparing the completeness of digestion methods, composite sampling was used. Composite sampling avoided physically disrupting soil aggregates and provided a more demanding digestion examination. Depending on digestion method, each experimental unit consisted of approximately $0.5 \mathrm{~g}$ or $1.5 \mathrm{~g}$ of soil and was obtained by compositing repeated subsamples from one bulk soil sample. Each experimental unit comprised at least four composited subsamples, and the bulk sample was mixed between taking subsamples.

\section{Digestion methods}

Digestion methods included the EPA SW-846 Method 3050 and the United States Army Toxic and Hazardous Waste Material Agency (USATHAMA) proposed R-9 microwave digestion procedure (USEPA 1986, Hewitt and Reynolds 1990). In addition, a block digestion method frequently used for routine digestion of large numbers of samples was included (Iskandar and Keeney 1974). Detailed descriptions of the EPA method and the microwave method are provided in the references.

In brief, EPA Method 3050 is a classic open-vessel, hot-plate digestion using $\mathrm{HNO}_{3}, \mathrm{H}_{2} \mathrm{O}_{2}$, and $\mathrm{HCL}$. Completion of digestion is a function of subjective interpretation by the laboratory analyst.

The proposed microwave digestion method uses closed Teflon or Teflon-lined bombs placed in a rotating rack within a microwave oven. The digesting solution is concentrated $\mathrm{HNO}_{3}$. A two-step, timed digestion procedure is used to limit frothing and promote complete digestion.

The block digestion technique is a modification of traditional hot-plate methods. Digestion tubes containing the sample, $\mathrm{HNO}_{3}$, and $\mathrm{HClO}_{4}$ are placed into fitted, cylindrical holes machined into an aluminum block. The entire block is then heated on a large hot-plate. The advantages of this method are a smaller laboratory footprint for the digestion apparatus, some degree of throughput improvement due to the simultaneous handling of tubes, and some explosion protection due to the tendency of the digestion block to direct forces. Sample digests were analyzed by graphite furnace atomic spectroscopy as described by Hewitt and Reynolds (1990).

\section{Laboratory protocol}

Because the objective presupposed evaluating the methodologies in rigorous and lifelike circumstances, explicit efforts were made to provide realistic soil con- 
tamination that challenged the digestion procedures and to remove or limit opportunities for unintentional bias or inadvertent data screening during the laboratory phase. The primary consideration in meeting the first of these criteria-obtaining authentic, aged, contaminated soils-has already been described.

A number of steps were taken to address the two remaining criteria. Primarily, precautions focused on incorporating and evaluating, rather than removing, the variability and errors that may occur in a typical routine laboratory process handling large numbers of samples. Extensive efforts were made to eliminate the ability to judge data prior to acceptance or rejection. Four laboratory personnel were involved in sample handling, including weighing, reagent transfers, digestion observations, filtration and dilution steps, and instrument operation. To avoid systematic bias for the overall analysis, different personnel were involved within each replication. For each procedural step, such as weighing samples for a digestion cycle or diluting solutions, one person would complete the task, but a different person would typically perform the following step, such as introducing the reagents for digestion. Although some procedures necessitated knowledge of the sample being handled, most of the laboratory steps involved coded laboratory containers, resulting in an essentially blind study. In situations where an action that could result in increased potential for introducing an error was realized or suspected before obtaining results, such as in sample weighing or solution diluting, the particular procedure was permitted to be repeated. The data were not screened for uniformity nor were excess replications conducted from which data could be selected. However, the data were reviewed to confirm the completeness of the statistical design.

\section{Experimental design}

This project was conducted as a $4 \times 12 \times 3$ factorial. The factors were digestion treatments, soils, and three digestion replications. Three digestion methods have been described above. As a fourth digestion treatment, an identical microwave digestion was included. This additional microwave digestion, statistically treated as a separate digestion treatment, allowed further evaluation of microwave digestion within the same balanced design. Eleven soils were included. A blank treatment, consisting of all required reagents but no soil, was included and treated as an additional soil treatment to compare the effects of digestion method on contamination. Results from blanks are therefore treated as hypothetical soil values rather than being subtracted from corresponding digestion results.

Commercially available microwave digestion equipment can generally handle a maximum of only 12 sam- ples at one time during a digestion cycle. Variables such as time, pressure, and temperature determine digestion completeness and are likely to be more uniform within a digestion cycle than among digestion cycles. Because the objectives included estimating the variability associated with each soil digestion procedure, the replications were blocked on time. For each digestion method, each of three blocks (replications) included one replication of all 12 soils. Blocking on time for digestion replicates permitted the replicate variability to be evaluated for each digestion method using a number of soils.

Significant effects of the treatments on means were evaluated using analysis of variance (ANOVA) procedures; means were separated and compared using Duncan's multiple range test (DMRT). For significant interactions, means of experimental units were analyzed by individual treatments within a factor and separated and compared using DMRT.

\section{RESULTS AND DISCUSSION}

\section{Means}

The main effects of soil and digestion method and the block effects were tested using ANOVA for randomized complete block designs. The ANOVA results demonstrated very highly significant $(P<0.001)$ main effects for digestion method and soil, as well as a significant method $\times$ soil interaction (Table 1 ). Overall, the effect of blocking (digestion replication) was significant at the $5 \%$ level. A significant difference in zinc concentrations among soils was expected, as the experiments evaluated a number of soils of varying levels of zinc contamination. The zinc concentration means, averaged for all digestion methods and separated using DMRT, are listed by soil in Table 2 . These differences demonstrated that the soil samples used in this study had a wide range of zinc concentrations, from $265 \mu \mathrm{g} / \mathrm{g}$ to

Table 1. Results of two-way ANOVA for randomized complete block design for all data blocked on replicates.

\begin{tabular}{lrc}
$\quad$ Source & $d f$ & Significance \\
\hline Blocks & 2 & $*$ \\
Main effects & & \\
$\quad$ Method & 3 & $\dagger$ \\
$\quad$ Soil & 11 & $\dagger$ \\
Interaction & & \\
$\quad$ Method $\times$ soil & 33 & $\dagger$ \\
Error & 94 & \\
Total & 143 & \\
\hline
\end{tabular}

* Indicates significance at the 0.05 level

$\dagger$ Indicates significance at the 0.001 level 
Table 2. Duncan's multiple range test for comparing zinc levels in soils, using means of digestion methods, at the 0.01 significance level

\begin{tabular}{rrrrc} 
Rank & $\begin{array}{c}\text { Soil } \\
\text { no. }\end{array}$ & $\begin{array}{c}\mathrm{Zn} \\
(\mu g / g)\end{array}$ & $n$ & $\begin{array}{c}\text { Nonsignificant } \\
\text { ranges }\end{array}$ \\
\hline \multicolumn{7}{c}{$r$} & & & \\
2 & 2 & 10849 & 12 & a \\
3 & 3 & 8984 & 12 & a \\
4 & 1 & 4555 & 12 & b \\
5 & 5 & 3252 & 12 & bc \\
6 & 10 & 2476 & 12 & bcd \\
7 & 6 & 1968 & 12 & bcd \\
8 & 7 & 1732 & 12 & bcd \\
9 & 8 & 1511 & 12 & cd \\
10 & 11 & 779 & 12 & cd \\
11 & 9 & 265 & 12 & d \\
12 & $12 \dagger$ & 28 & 12 & d \\
* Means followed by similar letters are not \\
significantly different as determined by DMRT. \\
$\dagger$ Blank.
\end{tabular}

more than $10,849 \mu \mathrm{g} / \mathrm{g}$, thereby providing extensive testing of the digestion methods.

Overall, there was a significant difference in digestion completeness among the digestion methods. Considering all the soils as a pool, there was no significant difference between the two microwave digestion treatments or between the EPA 3050 and block digestion methods (Table 3). Among all the soils pooled, the microwave digestion resulted in more complete metal release and greater metal concentration values than did either the EPA 3050 or block digestion methods.

A significant method $x$ soil interaction indicated that the effect of the digestion method was not constant among the soils. It is reasonable to assume that differences in digestion efficacy might vary with other factors associated with soils, such as degree of metal concentration, time since contamination occurred, or natural processes that may have occurred since contamination. Because the soil $\times$ digestion-method interaction was significant, each soil was evaluated individually for the main effects of the digestion method using ANOVA for

Table 3. Duncan's multiple range test for comparing effects of digestion method among means of all soils at the 0.01 significance level.

\begin{tabular}{clccc} 
Rank & $\begin{array}{c}\text { Digestion } \\
\text { method }\end{array}$ & $\begin{array}{c}\mathrm{Zn} \\
(\mu \mathrm{g} / \mathrm{g})\end{array}$ & $n$ & $\begin{array}{c}\text { Nonsignificant } \\
\text { ranges* }\end{array}$ \\
\hline & & & & \\
1 & Microwave 2 & 4748 & 36 & a \\
2 & Microwave 1 & 4443 & 36 & a \\
3 & Block digestion & 2038 & 36 & b \\
4 & 3050 & 1592 & 36 & b \\
\hline
\end{tabular}

* Means followed by similar letters are not significantly different as determined by DMRT.
Table 4. Means of zinc values by method $\times$ soil.

\begin{tabular}{crcrr} 
Soil & \multicolumn{5}{c}{ Digestion method } \\
\cline { 2 - 5 } no. & 3050 & Block digester & Microwave & Microwave \\
\hline & & & & \\
1 & $677 \mathrm{c}$ & $3126 \mathrm{bc}$ & $5916 \mathrm{ab}$ & $8503 \mathrm{a}$ \\
2 & $9304 \mathrm{a}$ & $6304 \mathrm{a}$ & $12534 \mathrm{a}$ & $15256 \mathrm{a}$ \\
3 & $2400 \mathrm{~b}$ & $4334 \mathrm{~b}$ & $13218 \mathrm{a}$ & $15986 \mathrm{a}$ \\
4 & $1331 \mathrm{a}$ & $1967 \mathrm{a}$ & $6422 \mathrm{a}$ & $3289 \mathrm{a}$ \\
5 & $1296 \mathrm{~b}$ & $1642 \mathrm{~b}$ & $3113 \mathrm{a}$ & $3855 \mathrm{a}$ \\
6 & $927 \mathrm{a}$ & $1624 \mathrm{a}$ & $3913 \mathrm{a}$ & $1400 \mathrm{a}$ \\
7 & $603 \mathrm{a}$ & $1582 \mathrm{a}$ & $2450 \mathrm{a}$ & $2294 \mathrm{a}$ \\
8 & $954 \mathrm{a}$ & $1519 \mathrm{a}$ & $2303 \mathrm{a}$ & $1271 \mathrm{a}$ \\
9 & $176 \mathrm{a}$ & $1991 \mathrm{a}$ & $374 \mathrm{a}$ & $315 \mathrm{a}$ \\
10 & $1025 \mathrm{a}$ & $1549 \mathrm{a}$ & $1880 \mathrm{a}$ & $3819 \mathrm{a}$ \\
11 & $352 \mathrm{~b}$ & $600 \mathrm{~b}$ & $1181 \mathrm{a}$ & $985 \mathrm{a}$ \\
12 & $64 \mathrm{a}$ & $19 \mathrm{a}$ & $16 \mathrm{a}$ & $14 \mathrm{a}$ \\
\hline
\end{tabular}

Means within rows followed by the same letter are not significantly different at the 0.01 level as determined by DMRT.

a completely random design. For significant main effects, Duncan's multiple range test was again used to separate the replication means for each digestion method within each soil (Table 4). Although significantly greater amounts of zinc were more frequently released by microwave digestion than by either of the other two methods, the variability in differences of zinc release by digestion treatments among soils is evident when the soils are listed individually. For soils $1,3,5$, and 11, microwave digestion yielded significantly greater zinc release than did Method 3050 (Table 4). For the other soils, the extent of variability within the bulk sample that was not successfully addressed by compositing a number of subsamples may have masked possible digestion-method differences.

Table 5. Summary of ANOVA by soil, significance of digestion method, and blocking effects on zinc release.

\begin{tabular}{ccccc}
$\begin{array}{c}\text { Soil } \\
\text { no. }\end{array}$ & $\begin{array}{c}\text { Zn } \\
(\mu g / g)\end{array}$ & $n$ & $\begin{array}{c}\text { Digestion } \\
\text { method }\end{array}$ & $\begin{array}{c}\text { Block } \\
\text { effect }\end{array}$ \\
\hline 2 & 10849 & 12 & $\mathrm{~ns}^{*}$ & $\mathrm{~ns}$ \\
3 & 8984 & 12 & $0.01^{\dagger}$ & 0.05 \\
1 & 4555 & 12 & 0.001 & $\mathrm{~ns}$ \\
4 & 3252 & 12 & $\mathrm{~ns}$ & $\mathrm{~ns}$ \\
5 & 2476 & 12 & 0.001 & $\mathrm{~ns}$ \\
10 & 2068 & 12 & $\mathrm{~ns}$ & $\mathrm{~ns}$ \\
6 & 1966 & 12 & $\mathrm{~ns}$ & $\mathrm{~ns}$ \\
7 & 1732 & 12 & $\mathrm{~ns}$ & $\mathrm{~ns}$ \\
8 & 1511 & 12 & $\mathrm{~ns}$ & $\mathrm{~ns}$ \\
11 & 779 & 12 & 0.001 & 0.01 \\
9 & 265 & 12 & $\mathrm{~ns}$ & $\mathrm{~ns}$ \\
12 (blanks) & 28 & 12 & $\mathrm{~ns}$ & $\mathrm{~ns}$ \\
\hline
\end{tabular}

* ns indicates nonsignificance at the 0.05 level.

$\dagger$ Numbers refer to significance level as determined by ANOVA for randomized complete block. 


\section{Variability}

The ranked means of all digestion methods within soils and the summary of ANOVA results for digestion method effects and block effects are given in Table 5. When ranked in order of degree of contamination, based on the means of the digestion methods, there was an apparent trend for greater variability among digestion replicates for more contaminated soils. This could be caused by the natural heterogeneity and spatial variability of the contamination and the resulting difficulty in obtaining uniform samples. The general lack of a significant block effect indicated that blocking on time was not a significant factor affecting variability. The large within-sample heterogeneity, the difficulty in obtaining uniform subsamples for digestion, and the resulting variability may have predominated and masked smaller but real differences in digestion-cycle blocking effects. In all cases, microwave digestion resulted in measured zinc concentrations that were equal to or greater than those determined from either EPA Method 3050 or the block digestion methods.

It is useful to identify and separate sources of variability to assist in focusing generally limited resources for optimum increase in precision. For each soil, the mean, standard deviation, and coefficient of variability (CV) are provided, respectively, for:

i) instrument analysis within digestion replicate and within digestion method

ii) digestion replications (blocks) within digestion method

iii) digestion methods

Data are provided for each soil in Tables 6 through 17. These data indicate that incomplete digestion occurred in some cases, such as digestion method 3050, digestion replication 1 , and the block digester method, digestion replication 2 , in Table 6 . Similar instances can be found for 10 of the soils. The uniformity for the microwave digestion replications is much greater.

Conversely, cases where contamination most probably occurred are also obvious. Reduced contamination is often cited as a benefit of microwave digestion. Sample 12, which was a series of blanks statistically treated as another soil sample rather than being subtracted from the soil values, provides insight into the digestionmethod effect on contamination (Table 17). The CV among digestion replications was $17.2 \%$ and $27.4 \%$ for microwave digestions, but $122.2 \%$ for Method 3050 . The descriptive statistics for the individual digestion replications indicated that replication 2 of the Method $3050,175.92 \mu \mathrm{g} / \mathrm{g}$, apparently was grossly contaminated compared with replications 1 and 3 , which were 9.11 and $8.44 \mu \mathrm{g} / \mathrm{g}$, respectively. Lack of significance in digestion methods for the blank treatment (Table 5) may have been hidden because of the large variability of the Method 3050 digestion. However, greater potential for gross contamination in the Method 3050 digestions would support the use of microwave digestion techniques.

Generally greater uniformity and more complete digestion, as evidenced by greater zinc values, occurred during microwave digestion. The $\mathrm{CV}$ values for instrument analysis ranged from $1.79 \%$ (Table 14) to $66.95 \%$ (Table 11). The average CV for instrumental analysis was $11.5 \%$. Of the total number of samples analyzed, $16 \%$ had an instrument $\mathrm{CV}$ greater than $20 \%$ and $7.6 \%$ had an instrument $\mathrm{CV}$ greater than $25 \%$. In a summary of numerous published reports, Markert (1990) estimated typical ranges of $2 \%$ to $20 \%$ for instrument-associated variability. The majority of these data are within the ranges reported by Markert, even though random

Table 6. Summary statistics for soil 1.

\begin{tabular}{|c|c|c|c|c|c|c|c|c|c|c|c|}
\hline \multirow[b]{2}{*}{ Soil } & \multirow{2}{*}{$\begin{array}{l}\text { Digestion } \\
\text { method }\end{array}$} & \multirow{2}{*}{$\begin{array}{l}\text { Digestion } \\
\text { replicate }\end{array}$} & \multicolumn{3}{|c|}{$\begin{array}{l}\text { Instrument analysis } \\
\text { replications }\end{array}$} & \multicolumn{3}{|c|}{$\begin{array}{l}\text { Digestion replications } \\
\text { by method }\end{array}$} & \multicolumn{3}{|c|}{$\begin{array}{c}\text { Descriptive statistics } \\
\text { by soil }\end{array}$} \\
\hline & & & $\overline{Z n}(\mu g / g)$ & Std dev & $C V$ & Mean & Std dev & $C V$ & Mean & Std dev & $C V$ \\
\hline 1 & 3050 & 1 & 156.96 & 4.86 & 3.10 & 677.12 & 370.08 & 54.66 & 4555.47 & 2937.67 & 64.49 \\
\hline 1 & & 2 & 886.94 & 85.31 & 9.62 & & & & & & \\
\hline 1 & & 3 & 987.44 & 181.58 & 18.39 & & & & & & \\
\hline 1 & Block digester & 1 & 3201.78 & 576.31 & 18.00 & 3125.63 & 1690.60 & 54.09 & & & \\
\hline 1 & & 2 & 1018.04 & 221.97 & 21.80 & & & & & & \\
\hline 1 & & 3 & 5157.06 & 1224.80 & 23.75 & & & & & & \\
\hline 1 & Microwave & 1 & 5447.53 & 342.23 & 6.28 & 5916.32 & 509.84 & 8.62 & & & \\
\hline 1 & & 2 & 6625.15 & 522.12 & 7.88 & & & & & & \\
\hline 1 & & 3 & 5676.29 & 1314.39 & 23.16 & & & & & & \\
\hline 1 & Microwave & 1 & 8001.30 & 988.02 & 12.35 & 8502.82 & 363.80 & 4.28 & & & \\
\hline 1 & & 2 & 8852.98 & 842.96 & 9.52 & & & & & & \\
\hline 1 & & 3 & 8654.18 & 2601.34 & 30.06 & & & & & & \\
\hline
\end{tabular}


Table 7. Summary statistics for soil 2.

\begin{tabular}{|c|c|c|c|c|c|c|c|c|c|c|c|}
\hline \multirow[b]{2}{*}{ Soil } & \multirow{2}{*}{$\begin{array}{c}\text { Digestion } \\
\text { method }\end{array}$} & \multirow{2}{*}{$\begin{array}{l}\text { Digestion } \\
\text { replicate }\end{array}$} & \multicolumn{3}{|c|}{$\begin{array}{l}\text { Instrument analysis } \\
\text { replications }\end{array}$} & \multicolumn{3}{|c|}{$\begin{array}{c}\text { Digestion replications } \\
\text { by method }\end{array}$} & \multicolumn{3}{|c|}{$\begin{array}{c}\text { Descriptive statistics } \\
\text { by soil }\end{array}$} \\
\hline & & & $Z n(\mu g / g)$ & Std dev & $C V$ & Mean & Std dev & $C V$ & Mean & Std dev & $C V$ \\
\hline 2 & 3050 & 1 & 880.27 & 84.66 & 9.62 & 9303.89 & 6610.56 & 71.05 & 10849.54 & 3365.38 & 31.02 \\
\hline 2 & & 2 & 17027.29 & 798.21 & 4.69 & & & & & & \\
\hline 2 & & 3 & 10004.10 & 542.61 & 5.42 & & & & & & \\
\hline 2 & Block digester & 1 & 5912.61 & 677.10 & 11.45 & 6304.26 & 611.19 & 9.69 & & & \\
\hline 2 & & 2 & 7167.38 & 596.44 & 8.32 & & & & & & \\
\hline 2 & & 3 & 5832.80 & 1049.88 & 18.00 & & & & & & \\
\hline 2 & Microwave & 1 & 9644.66 & 1427.38 & 14.80 & 12533.94 & 2913.68 & 23.25 & & & \\
\hline 2 & & 2 & 11434.30 & 497.73 & 4.35 & & & & & & \\
\hline 2 & & 3 & 16522.85 & 613.70 & 3.71 & & & & & & \\
\hline 2 & Microwave & 1 & 11814.56 & 662.79 & 5.61 & 15256.07 & 3867.93 & 25.35 & & & \\
\hline 2 & & 2 & 13294.65 & 0.00 & 0.00 & & & & & & \\
\hline 2 & & 3 & 20658.99 & 4509.82 & 21.83 & & & & & & \\
\hline
\end{tabular}

Table 8. Summary statistics for soil 3.

\begin{tabular}{|c|c|c|c|c|c|c|c|c|c|c|c|}
\hline \multirow[b]{2}{*}{ Soil } & \multirow{2}{*}{$\begin{array}{c}\text { Digestion } \\
\text { method }\end{array}$} & \multirow{2}{*}{$\begin{array}{l}\text { Digestion } \\
\text { replicate }\end{array}$} & \multicolumn{3}{|c|}{$\begin{array}{c}\text { Instrument analysis } \\
\text { replications }\end{array}$} & \multicolumn{3}{|c|}{$\begin{array}{c}\text { Digestion replications } \\
\text { by method }\end{array}$} & \multicolumn{3}{|c|}{$\begin{array}{c}\text { Descriptive statistics } \\
\text { by soil }\end{array}$} \\
\hline & & & $Z n(\mu g / g)$ & Std dev & $C V$ & Mean & Std dev & $C V$ & Mean & Std dev & $C V$ \\
\hline 3 & 3050 & 1 & 808.73 & 69.91 & 8.64 & 2400.43 & 2338.93 & 97.44 & 8984.63 & 5742.77 & 63.92 \\
\hline 3 & & 2 & 685.15 & 103.94 & 15.17 & & & & & & \\
\hline 3 & & 3 & 5707.41 & 1267.79 & 22.21 & & & & & & \\
\hline 3 & Block digester & 1 & 5193.67 & 241.72 & 4.65 & 4334.09 & 791.22 & 18.26 & & & \\
\hline 3 & & 2 & 3283.91 & 544.03 & 16.57 & & & & & & \\
\hline 3 & & 3 & 4524.69 & 1368.84 & 30.25 & & & & & & \\
\hline 3 & Microwave & 1 & 11375.86 & 245.83 & 2.16 & 13218.42 & 4315.29 & 32.65 & & & \\
\hline 3 & & 2 & 9101.22 & 193.72 & 2.13 & & & & & & \\
\hline 3 & & 3 & 19178.18 & 7949.70 & 41.45 & & & & & & \\
\hline 3 & Microwave & 1 & 12277.75 & 456.03 & 3.71 & 15985.59 & 5263.56 & 32.93 & & & \\
\hline 3 & & 2 & 12249.64 & 1685.66 & 13.76 & & & & & & \\
\hline 3 & & 3 & 23429.36 & 5663.76 & 24.17 & & & & & & \\
\hline
\end{tabular}

Table 9. Summary statistics for soil 4.

\begin{tabular}{|c|c|c|c|c|c|c|c|c|c|c|c|}
\hline \multirow[b]{2}{*}{ Soil } & \multirow{2}{*}{$\begin{array}{c}\text { Digestion } \\
\text { method }\end{array}$} & \multirow{2}{*}{$\begin{array}{l}\text { Digestion } \\
\text { replicate }\end{array}$} & \multicolumn{3}{|c|}{$\begin{array}{c}\text { Instrument analysis } \\
\text { replications }\end{array}$} & \multicolumn{3}{|c|}{$\begin{array}{c}\text { Digestion replications } \\
\text { by method }\end{array}$} & \multicolumn{3}{|c|}{$\begin{array}{c}\text { Descriptive statistics } \\
\text { by soil }\end{array}$} \\
\hline & & & $\overline{Z n(\mu g / g)}$ & Std dev & $C V$ & Mean & Std dev & $C \overline{C V}$ & Mean & Std dev & $C V$ \\
\hline 4 & 3050 & 1 & 546.54 & 19.30 & 3.53 & 1331.42 & 1014.89 & 76.23 & 3252.22 & 1961.28 & 60.31 \\
\hline 4 & & 2 & 683.20 & 124.41 & 18.21 & & & & & & \\
\hline 4 & & 3 & 2764.53 & 254.67 & 9.21 & & & & & & \\
\hline 4 & Block digester & 1 & 2223.43 & 773.56 & 34.79 & 1967.20 & 341.22 & 17.35 & & & \\
\hline 4 & & 2 & 2193.21 & 624.58 & 28.48 & & & & & & \\
\hline 4 & & 3 & 1484.96 & 96.60 & 6.50 & & & & & & \\
\hline 4 & Microwave & 1 & 4157.58 & 345.29 & 8.31 & 6421.50 & 4122.79 & 64.20 & & & \\
\hline 4 & & 2 & 12206.64 & 453.39 & 3.71 & & & & & & \\
\hline 4 & & 3 & 2900.28 & 292.73 & 10.09 & & & & & & \\
\hline 4 & Microwave & 1 & 3617.40 & 157.46 & 4.35 & 3288.75 & 776.74 & 23.62 & & & \\
\hline 4 & & 2 & 4032.17 & 85.82 & 2.13 & & & & & & \\
\hline 4 & & 3 & 2216.69 & 305.04 & 13.76 & & & & & & \\
\hline
\end{tabular}


Table 10. Summary statistics for soil 5.

\begin{tabular}{|c|c|c|c|c|c|c|c|c|c|c|c|}
\hline \multirow[b]{2}{*}{ Soil } & \multirow{2}{*}{$\begin{array}{c}\text { Digestion } \\
\text { method }\end{array}$} & \multirow{2}{*}{$\begin{array}{l}\text { Digestion } \\
\text { replicate }\end{array}$} & \multicolumn{3}{|c|}{$\begin{array}{l}\text { Instrument analysis } \\
\text { replications }\end{array}$} & \multicolumn{3}{|c|}{$\begin{array}{c}\text { Digestion replications } \\
\text { by method }\end{array}$} & \multicolumn{3}{|c|}{$\begin{array}{c}\text { Descriptive statistics } \\
\text { by soil }\end{array}$} \\
\hline & & & $Z n(\mu g / g)$ & Std dev & $C V$ & Mean & Std dev & $C V$ & Mean & Std dev & $\mathrm{CV}$ \\
\hline 5 & 3050 & 1 & 249.64 & 9.04 & 3.62 & 1296.39 & 790.35 & 60.97 & 2476.73 & 1048.21 & 42.32 \\
\hline 5 & & 2 & 1480.34 & 26.65 & 1.80 & & & & & & \\
\hline 5 & & 3 & 2159.18 & 350.79 & 16.25 & & & & & & \\
\hline 5 & Block digester & 1 & 1562.40 & 96.05 & 6.15 & 1642.23 & 59.36 & 3.61 & & & \\
\hline 5 & & 2 & 1704.61 & 357.48 & 20.97 & & & & & & \\
\hline 5 & & 3 & 1659.69 & 107.96 & 6.50 & & & & & & \\
\hline 5 & Microwave & 1 & 2735.99 & 115.54 & 4.22 & 3112.94 & 280.01 & 8.99 & & & \\
\hline 5 & & 2 & 3406.48 & 214.00 & 6.28 & & & & & & \\
\hline 5 & & 3 & 3196.34 & 354.04 & 11.08 & & & & & & \\
\hline 5 & Microwave & 1 & 3537.53 & 0.00 & 0.00 & 3855.36 & 361.04 & 9.36 & & & \\
\hline 5 & & 2 & 3668.22 & 78.08 & 2.13 & & & & & & \\
\hline 5 & & 3 & 4360.34 & 739.08 & 16.95 & & & & & & \\
\hline
\end{tabular}

Table 11. Summary statistics for soil 6.

\begin{tabular}{|c|c|c|c|c|c|c|c|c|c|c|c|}
\hline \multirow[b]{2}{*}{ Soil } & \multirow{2}{*}{$\begin{array}{l}\text { Digestion } \\
\text { method }\end{array}$} & \multirow{2}{*}{$\begin{array}{l}\text { Digestion } \\
\text { replicate }\end{array}$} & \multicolumn{3}{|c|}{$\begin{array}{c}\text { Instrument analysis } \\
\text { replications }\end{array}$} & \multicolumn{3}{|c|}{$\begin{array}{c}\text { Digestion replications } \\
\text { by method }\end{array}$} & \multicolumn{3}{|c|}{$\begin{array}{c}\text { Descriptive statistics } \\
\text { by soil }\end{array}$} \\
\hline & & & $Z n(\mu g / g)$ & Std dev & $\mathrm{CV}$ & Mean & Std dev & $C V$ & Mean & Std dev & $\mathrm{CV}$ \\
\hline 6 & 3050 & 1 & 134.03 & 7.32 & 5.46 & 926.96 & 564.34 & 60.88 & 1966.01 & 1151.74 & 58.58 \\
\hline 6 & & 2 & 1244.82 & 22.41 & 1.80 & & & & & & \\
\hline 6 & & 3 & 1402.01 & 65.25 & 4.65 & & & & & & \\
\hline 6 & Block digester & 1 & 2255.92 & 1510.40 & 66.95 & 1624.07 & 516.56 & 31.81 & & & \\
\hline 6 & & 2 & 990.62 & 54.18 & 5.47 & & & & & & \\
\hline 6 & & 3 & 1625.66 & 391.22 & 24.07 & & & & & & \\
\hline 6 & Microwave & 1 & 943.28 & 54.08 & 5.73 & 3912.67 & 3888.41 & 99.38 & & & \\
\hline 6 & & 2 & 1389.05 & 29.57 & 2.13 & & & & & & \\
\hline 6 & & 3 & 9405.68 & 349.35 & 3.71 & & & & & & \\
\hline 6 & Microwave & 1 & 1287.94 & 277.06 & 21.51 & 1400.36 & 475.27 & 33.94 & & & \\
\hline 6 & & 2 & 2030.46 & 75.42 & 3.71 & & & & & & \\
\hline 6 & & 3 & 882.69 & 32.79 & 3.71 & & & & & & \\
\hline
\end{tabular}

Table 12. Summary statistics for soil 7.

\begin{tabular}{|c|c|c|c|c|c|c|c|c|c|c|c|}
\hline \multirow[b]{2}{*}{ Soil } & \multirow{2}{*}{$\begin{array}{c}\text { Digestion } \\
\text { method }\end{array}$} & \multirow{2}{*}{$\begin{array}{l}\text { Digestion } \\
\text { replicate }\end{array}$} & \multicolumn{3}{|c|}{$\begin{array}{l}\text { Instrument analysis } \\
\text { replications }\end{array}$} & \multicolumn{3}{|c|}{$\begin{array}{c}\text { Digestion replications } \\
\text { by method }\end{array}$} & \multicolumn{3}{|c|}{$\begin{array}{c}\text { Descriptive statistics } \\
\text { by soil }\end{array}$} \\
\hline & & & $Z n(\mu g / g)$ & Std dev & $C V$ & Mean & Std dev & $\overrightarrow{C V}$ & Mean & Std dev & $C V$ \\
\hline 7 & 3050 & 1 & 171.99 & 3.10 & 1.80 & 602.54 & 306.73 & 50.91 & 1732.01 & 729.67 & 42.1 \\
\hline 7 & & 2 & 863.60 & 15.54 & 1.80 & & & & & & \\
\hline 7 & & 3 & 772.04 & 105.49 & 13.66 & & & & & & \\
\hline 7 & Block digester & 1 & 1781.20 & 405.06 & 22.74 & 1581.58 & 242.44 & 15.33 & & & \\
\hline 7 & & 2 & 1723.18 & 449.12 & 26.06 & & & & & & \\
\hline 7 & & 3 & 1240.36 & 624.80 & 50.37 & & & & & & \\
\hline 7 & Microwave & 1 & 3304.34 & 832.66 & 25.20 & 2450.20 & 756.64 & 30.88 & & & \\
\hline 7 & & 2 & 2581.33 & 54.94 & 2.13 & & & & & & \\
\hline 7 & & 3 & 1464.92 & 492.24 & 33.60 & & & & & & \\
\hline 7 & Microwave & 1 & 2122.70 & 45.87 & 2.16 & 2293.74 & 1006.71 & 43.89 & & & \\
\hline 7 & & 2 & 3603.29 & 650.62 & 18.06 & & & & & & \\
\hline 7 & & 3 & 1155.22 & 170.97 & 14.80 & & & & & & \\
\hline
\end{tabular}


Table 13. Summary statistics for soil 8.

\begin{tabular}{|c|c|c|c|c|c|c|c|c|c|c|c|}
\hline \multirow[b]{2}{*}{ Soil } & \multirow{2}{*}{$\begin{array}{l}\text { Digestion } \\
\text { method }\end{array}$} & \multirow{2}{*}{$\begin{array}{l}\text { Digestion } \\
\text { replicate }\end{array}$} & \multicolumn{3}{|c|}{$\begin{array}{l}\text { Instrument analysis } \\
\text { replications }\end{array}$} & \multicolumn{3}{|c|}{$\begin{array}{c}\text { Digestion replications } \\
\text { by method }\end{array}$} & \multicolumn{3}{|c|}{$\begin{array}{c}\text { Descriptive statistics } \\
\text { by soil }\end{array}$} \\
\hline & & & $Z n(\mu g / g)$ & Std dev & $C V$ & Mean & Std dev & $C V$ & Mean & Std dev & $C V$ \\
\hline 8 & 3050 & 1 & 68.14 & 3.58 & 5.26 & 953.83 & 944.14 & 98.98 & 1511.62 & 498.76 & 32.99 \\
\hline 8 & & 2 & 531.37 & 32.90 & 6.19 & & & & & & \\
\hline 8 & & 3 & 2261.99 & 208.39 & 9.21 & & & & & & \\
\hline 8 & Block digester & 1 & 1590.88 & 318.91 & 20.05 & 1518.91 & 196.63 & 12.95 & & & \\
\hline 8 & & 2 & 1250.32 & 95.78 & 7.66 & & & & & & \\
\hline 8 & & 3 & 1715.54 & 81.29 & 4.74 & & & & & & \\
\hline 8 & Microwave & 1 & 1529.73 & 64.60 & 4.22 & 2302.79 & 1474.75 & 64.04 & & & \\
\hline 8 & & 2 & 4366.85 & 403.06 & 9.23 & & & & & & \\
\hline 8 & & 3 & 1011.78 & 117.00 & 11.56 & & & & & & \\
\hline 8 & Microwave & 1 & 1097.74 & 81.48 & 7.42 & 1270.95 & 184.86 & 14.54 & & & \\
\hline 8 & & 2 & 1527.14 & 32.50 & 2.13 & & & & & & \\
\hline 8 & & 3 & 1187.98 & 25.67 & 2.16 & & & & & & \\
\hline
\end{tabular}

Table 14. Summary statistics for soil 9.

\begin{tabular}{|c|c|c|c|c|c|c|c|c|c|c|c|}
\hline \multirow[b]{2}{*}{ Soil } & \multirow{2}{*}{$\begin{array}{c}\text { Digestion } \\
\text { method }\end{array}$} & \multirow{2}{*}{$\begin{array}{l}\text { Digestion } \\
\text { replicate }\end{array}$} & \multicolumn{3}{|c|}{$\begin{array}{c}\text { Instrument analysis } \\
\text { replications }\end{array}$} & \multicolumn{3}{|c|}{$\begin{array}{c}\text { Digestion replications } \\
\text { by method }\end{array}$} & \multicolumn{3}{|c|}{$\begin{array}{c}\text { Descriptive statistics } \\
\text { by soil }\end{array}$} \\
\hline & & & $Z n(\mu g / g)$ & Std dev & $C V$ & Mean & Std dev & $C V$ & Mean & Std dev & $C V$ \\
\hline 9 & 3050 & 1 & 125.10 & 3.88 & 3.10 & 176.06 & 51.22 & 29.09 & 65.90 & 81.74 & 30.74 \\
\hline 9 & & 2 & 246.11 & 4.43 & 1.80 & & & & & & \\
\hline 9 & & 3 & 156.95 & 2.80 & 1.79 & & & & & & \\
\hline 9 & Block digester & 1 & 173.14 & 14.22 & 8.21 & 198.54 & 18.12 & 9.12 & & & \\
\hline 9 & & 2 & 208.38 & 21.19 & 10.17 & & & & & & \\
\hline 9 & & 3 & 214.11 & 36.41 & 17.00 & & & & & & \\
\hline 9 & Micruwave & 1 & 259.10 & 5.60 & 2.16 & 374.16 & 197.52 & 52.79 & & & \\
\hline 9 & & 2 & 211.24 & 41.94 & 19.86 & & & & & & \\
\hline 9 & & 3 & 652.12 & 111.30 & 17.07 & & & & & & \\
\hline 9 & Microwave & 1 & 247.75 & 10.46 & 4.22 & 314.84 & 107.70 & 34.21 & & & \\
\hline 9 & & 2 & 229.97 & 4.89 & 2.13 & & & & & & \\
\hline 9 & & 3 & 466.80 & 9.94 & 2.13 & & & & & & \\
\hline
\end{tabular}

Table 15. Summary statistics for soil 10.

\begin{tabular}{|c|c|c|c|c|c|c|c|c|c|c|c|}
\hline \multirow[b]{2}{*}{ Soil } & \multirow{2}{*}{$\begin{array}{c}\text { Digestion } \\
\text { method }\end{array}$} & \multirow{2}{*}{$\begin{array}{l}\text { Digestion } \\
\text { replicate }\end{array}$} & \multicolumn{3}{|c|}{$\begin{array}{c}\text { Instrument analysis } \\
\text { replications }\end{array}$} & \multicolumn{3}{|c|}{$\begin{array}{c}\text { Digestion replications } \\
\text { by method }\end{array}$} & \multicolumn{3}{|c|}{$\begin{array}{c}\text { Descriptive statistics } \\
\text { by soil }\end{array}$} \\
\hline & & & $\overline{Z n}(\mu g / g)$ & Std dev & $C V$ & Mean & Std dev & $C V$ & Mean & Std dev & $C V$ \\
\hline 10 & 3050 & 1 & 123.49 & 7.65 & 6.19 & 1025.03 & 718.66 & 70.11 & 2068.36 & 1055.90 & 51.0 \\
\hline 10 & & 2 & 1069.45 & 162.24 & 15.17 & & & & & & \\
\hline 10 & & 3 & 1882.15 & 149.24 & 7.93 & & & & & & \\
\hline 10 & Block digester & 1 & 909.01 & 203.37 & 22.37 & 1549.44 & 742.02 & 47.89 & & & \\
\hline 10 & & 2 & 2589.57 & 753.85 & 29.11 & & & & & & \\
\hline 10 & & 3 & 1149.75 & 122.77 & 10.68 & & & & & & \\
\hline 10 & Microwave & 1 & 1879.07 & 0.00 & 0.00 & 1879.52 & 778.41 & 41.42 & & & \\
\hline 10 & & 2 & 2833.09 & 223.27 & 7.88 & & & & & & \\
\hline 10 & & 3 & 926.39 & 135.44 & 14.62 & & & & & & \\
\hline 10 & Microwave & 1 & 8434.58 & 0.00 & 0.00 & 3819.43 & 3284.39 & 85.99 & & & \\
\hline 10 & & 2 & 1965.85 & 110.28 & 5.61 & & & & & & \\
\hline 10 & & 3 & 1057.87 & 130.63 & 12.35 & & & & & & \\
\hline
\end{tabular}


Table 16. Summary statistics for soil 11.

\begin{tabular}{|c|c|c|c|c|c|c|c|c|c|c|c|}
\hline \multirow[b]{2}{*}{ Soil } & \multirow{2}{*}{$\begin{array}{c}\text { Digestion } \\
\text { method }\end{array}$} & \multirow{2}{*}{$\begin{array}{l}\text { Digestion } \\
\text { replicate }\end{array}$} & \multicolumn{3}{|c|}{$\begin{array}{l}\text { Instrument analysis } \\
\text { replications }\end{array}$} & \multicolumn{3}{|c|}{$\begin{array}{c}\text { Digestion replications } \\
\text { by method }\end{array}$} & \multicolumn{3}{|c|}{$\begin{array}{c}\text { Descriptive statistics } \\
\text { by soil }\end{array}$} \\
\hline & & & $Z n(\mu g / g)$ & Std dev & $\overline{C V}$ & Mean & Std dev & $\overline{C V}$ & Mean & Std dev & $\overline{C V}$ \\
\hline 11 & 3050 & 1 & 245.26 & 26.38 & 10.75 & 352.19 & 145.38 & 41.28 & 779.58 & 323.31 & 41.97 \\
\hline 11 & & 2 & 253.56 & 28.16 & 11.11 & & & & & & \\
\hline 11 & & 3 & 557.74 & 59.55 & 10.68 & & & & & & \\
\hline 11 & Block digester & 1 & 509.02 & 60.28 & 11.84 & 600.28 & 88.44 & 14.73 & & & \\
\hline 11 & & 2 & 571.84 & 17.59 & 3.08 & & & & & & \\
\hline 11 & & 3 & 719.98 & 66.33 & 9.21 & & & & & & \\
\hline 11 & Microwave & 1 & 1193.48 & 78.46 & 6.57 & 1181.05 & 197.43 & 16.72 & & & \\
\hline 11 & & 2 & 933.28 & 88.08 & 9.44 & & & & & & \\
\hline 11 & & 3 & 1416.40 & 105.14 & 7.42 & & & & & & \\
\hline 11 & Microwave & 1 & 978.76 & 42.61 & 4.35 & 984.81 & 181.99 & 18.48 & & & \\
\hline 11 & & 2 & 765.01 & 56.78 & 7.42 & & & & & & \\
\hline 11 & & 3 & 1210.66 & 294.18 & 24.30 & & & & & & \\
\hline
\end{tabular}

Table 17. Summary statistics for soil 12 (digestion blanks).

\begin{tabular}{|c|c|c|c|c|c|c|c|c|c|c|c|}
\hline \multirow[b]{2}{*}{ Soil } & \multirow{2}{*}{$\begin{array}{c}\text { Digestion } \\
\text { method }\end{array}$} & \multirow{2}{*}{$\begin{array}{l}\text { Digestion } \\
\text { replicate }\end{array}$} & \multicolumn{3}{|c|}{$\begin{array}{l}\text { Instrument analysis } \\
\text { replications }\end{array}$} & \multicolumn{3}{|c|}{$\begin{array}{c}\text { Digestion replications } \\
\text { by method }\end{array}$} & \multicolumn{3}{|c|}{$\begin{array}{c}\text { Descriptive statistics } \\
\text { by soil }\end{array}$} \\
\hline & & & $Z n(\mu g / g)$ & Std dev & $\overline{C V}$ & Mean & Std dev & $C V$ & Mean & Std dev & $C V$ \\
\hline 12 & 3050 & 1 & 9.11 & 0.85 & 9.28 & 64.49 & 78.80 & 122.18 & 28.54 & 20.84 & 73.04 \\
\hline 12 & & 2 & 175.92 & 18.12 & 10.30 & & & & & & \\
\hline 12 & & 3 & 8.44 & 0.30 & 3.60 & & & & & & \\
\hline 12 & Block digester & 1 & 18.44 & 0.57 & 3.08 & 19.29 & 2.22 & 11.53 & & & \\
\hline 12 & & 2 & 17.10 & 0.53 & 3.08 & & & & & & \\
\hline 12 & & 3 & 22.34 & 2.06 & 9.21 & & & & & & \\
\hline 12 & Microwave & 1 & 21.91 & 1.26 & 5.73 & 16.37 & 4.49 & 27.43 & & & \\
\hline 12 & & 2 & 16.30 & 3.71 & 22.79 & & & & & & \\
\hline 12 & & 3 & 10.91 & 0.72 & 6.57 & & & & & & \\
\hline 12 & Microwave & 1 & 14.18 & 1.64 & 11.56 & 13.99 & 2.41 & 17.23 & & & \\
\hline 12 & & 2 & 16.84 & 2.46 & 14.62 & & & & & & \\
\hline 12 & & 3 & 10.94 & 1.10 & 10.09 & & & & & & \\
\hline
\end{tabular}

rather than sequential instrument replications were used and instrument analyses were done blind to reduce the potential for data selection.

For each soil, the variability associated with digestion replications for each digestion method can be seen in Tables 6 through 17. Markert (1990) reported that sample preparation errors and sampling errors contribute from 100 to $300 \%$ and up to $1000 \%$, respectively. In this study, microwave digestions generally appeared to be more uniform among digestion replications than either EPA Method 3050 or the block digestion methods. For the two microwave digestion treatments, $\mathrm{CV}$ values for the means of digestion replications were $20.5 \%$ and $28.7 \%$, respectively (Table 18 ). The analogous value for the EPA Method 3050 was $69.5 \%$. Block digestion $\mathrm{CV}$ means were $39.2 \%$.
Table 18. Results of Duncan's multiple range test for comparing digestion method variability, expressed as $\mathrm{CV}$ of replications, at the 0.01 level.

\begin{tabular}{llccc} 
Rank & $\begin{array}{c}\text { Digestion } \\
\text { method }\end{array}$ & CV & $n$ & $\begin{array}{c}\text { Nonsignificant } \\
\text { ranges* }\end{array}$ \\
\hline & & & & \\
1 & 3050 & 69.48 & 12 & a \\
2 & Block & 39.19 & 12 & b \\
3 & Microwave 1 & 28.65 & 12 & b \\
4 & Microwave 2 & 20.52 & 12 & b \\
\hline
\end{tabular}

* Means followed by similar letters are not significantly different at the 0.01 level as determined by DMRT.

ANOVA procedures were used to compare statistically the variability, in terms of $\mathrm{CV}$ values, among digestion treatments. For the dependent variable, CV of 
Table 19. Summary of results of oneway ANOVA for completely random design comparing variability, expressed as $\mathrm{CV}$ of replications, of digestion methods for 12 soil treatments.

\begin{tabular}{lrc}
\multicolumn{1}{c}{ Source } & $d f$ & Significance \\
\hline Main effects method & 3 & $*$ \\
Error & 44 & \\
Total & 47 & \\
\hline
\end{tabular}

* Denotes significance at the 0.001 level.

digestion replications, the effect of each digestion method was tested. The soils served as 12 replications. The results indicated a significant difference among means for digestion methods at the 0.001 level (Table 19). Duncan's multiple range test was used to separate the means (Table 18). The variability associated with digestion replications, as expressed by digestion replication $\mathrm{CV}$, was significantly less for both microwave digestion methods and the block digestion method than for EPA Method 3050.

\section{CONCLUSIONS AND RECOMMENDATIONS}

Microwave digestions provide markedly faster digestion times for contaminated soil samples than other methods. In agreement with reported literature, zinc release using microwave digestions was equal to or greater than it was using other methods. Moreover, microwave digestions yielded less variability among digestion replications than did EPA Method 3050. This study indicates that microwave digestion methods are capable of providing faster, more complete, and more precise release of zinc from soils that have been contaminated and allowed to age while being subjected to natural weathering processes.

These data support the concept that variability within a soil sample presents significant challenges, both in obtaining uniform analytical results and in interpretation (Page et al. 1982, Peterson and Calvin 1982, Warrick et al. 1982, Markert 1990, Tatro 1990b). The first of these challenges can be addressed partially by extensive physical mixing. An alternative and perhaps more scientifically reasonable approach would be to use much larger samples for analysis, but this presents laboratory and waste disposal problems and diverges from traditional analytical tenets. Another alternative, use of geostatistics and spatial variability theory, could potentially provide a better understanding of the sampling intensity needed and improve the validity of conclusions that can be made from the resulting data. Geostatistical theory could be used advantageously to incorpo- rate spatial variability into better descriptions of the distribution of contaminants in soil. Such a technique could require more samples, but emphasis would be placed on describing and utilizing natural variability and reducing variability caused by sample handling and artifacts of the analysis. Subsequently, absolute levels of contaminant in soil samples would be less critical. Research to incorporate spatial variability into delineating concentration plumes in soils has been an area of intense investigation for many years (Peterson and Calvin 1982, Warrick et al. 1982). With the improved throughput that microwave digestion techniques provide, the coupling of these techniques would appear beneficial.

Although microwave digestion methods may presently be used for regulatory compliance and may be used with emerging engineering technologies aimed at environmental cleanup, clearly the more valuable use lies in the future, as more novel and innovative marriages with technologies such as metal speciation schemes, speciation and transport models and their validation, and bioavailability predictions are coupled with microwave methodology. In this way, microwave methods can be used to help improve our understanding of the processes that govern the fate of metals in soil.

\section{LITERATURE CITED}

Borman, S. (1986) Microwave dissolution. Analytical Chemistry, 58: 1424a-1428a.

Borman, S. (1988) Microwave dissolution. Analytical Chemistry, 60: 715a-716a.

Borman, S. (1990) Expert systems seeing greater use for environmental problem solving. ASM News, 56(3): 139-141.

Fischer, L.B. (1986) Microwave dissolution of geologic material: Application to isotope dilution analysis. Analytical Chemistry, 58: 261-263.

Gilman, L. and W.G. Engelhart (1988) Recent advances in microwave sample preparation. Spectroscopy, 4: 14 17.

Gilman, L. and W. Grooms (1988) Safety concerns associated with wet ashing samples under pressure heated by microwave energy. Analytical Chemistry, 60: 1624 1625.

Grillo, A.C. (1990) Microwave digestion using a closedvessel system. Spectroscopy, 5: 14-55.

Hewitt, A.D. and C.M. Reynolds (1990) Microwave digestion of soils and sediments for assessing contamination by hazardous waste metals. USA Cold Regions Research and Engineering Laboratory, Special Report 90-19.

Iskandar, I.K. and D.R. Keeney (1974) Concentration of heavy metals in sediment cores from selected Wiscon- 
sin lakes. Environmental Sciences and Technology, 8: 165-170.

Kammin,W.R. and M.J. Brandt (1989a) ICP-OES evaluation of microwave digestion. Spectroscopy, 4: 49-55. Kammin, W.R. and M.J. Brandt (1989b) The simulation of EPA Method 3050 using a high-temperature and pressure microwave bomb. Spectroscopy, 4: 23-24.

Kimbrough, D.E. and J.R. Wakakuwa (1989) Acid digestion for sediments, sludges, soils and solid wastes; A proposed alternative to EPA SW 846 Method 3050. Environmental Science and Technology, 23: 848-900. Kingston, H.M. and L.B. Jassie (1986) Microwave energy for acid decomposition at elevated temperatures and pressures using biological and botanical samples. Analytical Chemistry, 58: 2534-2541.

Kingston, H.M. and L.B. Jassie (Ed.) (1988) Introduction to microwave sample preparation: Theory and practice. Washington, D.C.: American Chemical Society.

Lamothe, P.J., T.L. Fries and J.J. Consul (1986) Evaluation of a microwave oven system for the dissolution of geologic samples. Analytical Chemistry, 58: 18811886.

Lautenschlaeger, W. (1989) Microwave digestion in a closed-vessel, high-pressure system. Spectroscopy, 4: 16-21.

Lim, C.H. and M.L. Jackson (1982) Dissolution for total elemental analysis. In Methods of Soil Analysis, Part 2, Chemical and Microbiological Properties (A.L. Page, R.H. Miller and D.R. Keeney, Ed.). Madison, Wisconsin: American Society of Agronomy, Inc. and Soil Science Society of America, Inc., second edition, p. 112.

Markert, B. (1990) Multi-element analysis in ecosystems-Analytical tools and biological questions. Paper presented at the International Conference on Metals in Soils, Waters, Plants and Animals, Orlando, Fla., April 30-May 3.

Matthes, S.A., R.F. Farrell and A.J. Mackie (1983) A microwave system for the acid dissolution of metal and mineral samples. Bureau of Mines Analytical Support Services Program, Technical Progress Report 120.

Nadkarni, R.A. (1984) Applications of microwave sample dissolution on analysis. Analytical Chemistry, 56: 2233-223.

Nakashima, S., R.E. Sturgeon, S.N. Willie and S.S. Berman (1988) Acid digestion of marine samples for trace element analysis using microwave heating. Analyst, 113: 159-163.

Neas, E.D. and M.J. Collins (1988) Microwave heating: Theoretical concepts and equipment design. In Introduction to microwave sample preparation: Theory and practice (H.M. Kingston and L.B. Jassie, Ed.). Washington, D.C.: American Chemical Society.
Page, A.L., R.H. Miller and D.R. Keeney (Ed.) (1982) Methods of soil analysis, Part 2, Chemical and microbiological properties. Madison, Wisc.: American Society of Agronomy, Inc. and Soil Science Society of America, Inc., second edition.

Palazzo, A.J. and C.M. Reynolds (1991) Long-term changes in soil and plant metal concentrations in an acidic dredge disposal site receiving sewage sludge. Water, Air and Soil Pollution, in press.

Peterson, R.G. and L.D. Calvin (1982) Sampling. In Methods of soil analysis, Part 1, Physical and mineralogical methods. (A. Klute, Ed.). Madison, Wisc.: American Society of Agronomy, Inc. and Soil Science Society of America, Inc., second edition, p. 33-52.

Rantala, R.T.T. and D.H. Loring (1989) Teflon bomb decomposition of silicate materials in a microwave oven. Analytica Chimica Acta, 220: 263-267.

Settle, F., B. Diamondstone, H. Kingston and M. Pleva (1989) An expert-database system for sample preparation by microwave dissolution. 1 . Selection of analytical descriptors. Journal of Chemical Information and Computer Science, 29: 11-17.

Skelly, E.M. and F.T. DiStefano (1988) Clean room and microwave digestion techniques: Improvement on detection limits for aluminum determination by GF-AAS. Applied Spectroscopy, 42: 1302-1306.

Smith, F. and B. Cousins (1985) The acid dissolution of sulfide mineral samples under pressure in a microwave oven. Analytica Chimica Acta, 177: 243-245.

Sulcek, Z. and P. Povondra (1989) Methods of decomposition in inorganic analysis. Boca Raton, Fla.: CRC Press, Inc.

Tatro, M.E. (1990a) Sample preparation: The weak link in atomic spectroscopy. Spectroscopy, 5(3): 15-17.

Tatro, M.E. (1990b) EPA approves closed-vessel microwave digestion for CLP laboratories. Spectroscopy, 5(4): 17-20.

Tessier, A., P.G.C. Campbell and M. Bisson (1979) Sequential extraction procedure for the speciation of particulate trace metals. Analytical Chemistry, 51: 844 851.

U.S. Environmental Protection Agency (1986) Method 3050 , acid digestion of sediments, sludges and soils. Test methods for evaluating solid waste. Vol. 1A: Laboratory manual, Physical/chemical methods. Washington, D.C.: U.S. Environmental Protection Agency. Warrick, A.W., D.E. Myers and D.R. Nielsen (1982) Geostatistical methods applied to soil science. In Methods of soil analysis, Part 1, Physical and mineralogical methods (A. Klute, Ed.). Madison, Wisc.: American Society of Agronomy, Inc. and Soil Science Society of America, Inc., second edition, p. 53-82. 


\section{REPORT DOCUMENTATION PAGE}

Public reporting burden for this collection of information is estimated to average 1 hour per response, including the time for reviewing instructions, searching existing data sources, gathering and maintaining the data needed, and completing and reviewing the collection of information. Send comments regarding this burden estimate or any other aspect of this collection of information, including suggestion for reducing this burden, to Washington Headquarters Services, Directorate for Information Operations and Reports, 1215 Jefferson Davis Highway, Suite 1204, Arlington, VA 22202-4302, and to the Office of Management and Budget, Paperwork Reduction Project (0704-0188), Washington, DC 20503.

\begin{tabular}{|l|l|l}
\hline 1. AGENCY USE ONLY (Leave blank) & $\begin{array}{c}\text { 2. REPORT DATE } \\
\text { August } 1992\end{array}$ & 3. REPORT TYPE AND DATES COVERED \\
\hline
\end{tabular}

4. TITLE AND SUBTITLE

5. FUNDING NUMBERS

Effectiveness and Variability of Digestion Procedures

R-90

for Zinc Determination in Aged, Contaminated Soils

PR 4A161102AT24

6. AUTHORS

Charles M. Reynolds

7. PERFORMING ORGANIZATION NAME(S) AND ADDRESS(ES)

8. PERFORMING ORGANIZATION REPORT NUMBER

U.S. Army Cold Regions Research and Engineering Laboratory

72 Lyme Road

CRREL Report 92-15

Hanover, New Hampshire 03755-1290

9. SPONSORING/MONITORING AGENCY NAME(S) AND ADDRESS(ES)

U.S. Army Toxic and Hazardous Materials Agency

D. SPONSORING/MONITORING AGENCY REPORT NUMBER

Aberdeen, Maryland

and

CETHA-TS-CR-91021

Office of the Chief of Engineers

Washington, D.C. 20314-1000

11. SUPPLEMENTARY NOTES

12a. DISTRIBUTION/AVAILABILITY STATEMENT

12b. DISTRIBUTION CODE

Approved for public release; distribution is unlimited.

Available from NTIS, Springfield, Virginia 22161.

13. ABSTRACT (Maximum 200 words)

Owing to the numerous advantages provided by microwave digestions, regulatory agencies are recognizing its value, yet most reported comparisons of microwave digestions with other accepted methods have used ores, laboratory-spiked soils, or soils with unexceptional, rather than elevated, metal concentrations. Objectives of this research included evaluating microwave digestion for routine laboratory use and comparing microwave, block digester, and hot-plate soil digestion techniques for determining zinc in aged, zinc-contaminated soils. Soil samples, chosen to provide a more realistic and rigorous test of the digestion procedures than would spike recovery methods and known to contain appreciable quantities of zinc, were collected from sites near a zinc smelter that had operated for more than 80 years. To obtain a range of zinc concentrations, surface $(0-20 \mathrm{~cm}$ ) samples of Weikert silt loam soil (loamy-skeletal, mixed, mesic, shallow Typic Dystrochrept) were collected from a location subject to airborne contamination from the smelter site. Very highly significant effects for digestion method, soil, and method $\times$ soil interaction were observed. Considering all the soils analyzed as a group, there was no significant difference in zinc release between two separate microwave digestions, or between the hot-plate and block digestion methods. However. microwave digestion resulted in significantly more complete metal release and greater metal concentration values than did either the hot-plate or block digestion methods. Effect of digestion method was not constant among soils. Uniformity for the microwave digestion replications was better than for either block or hot-plate methods.

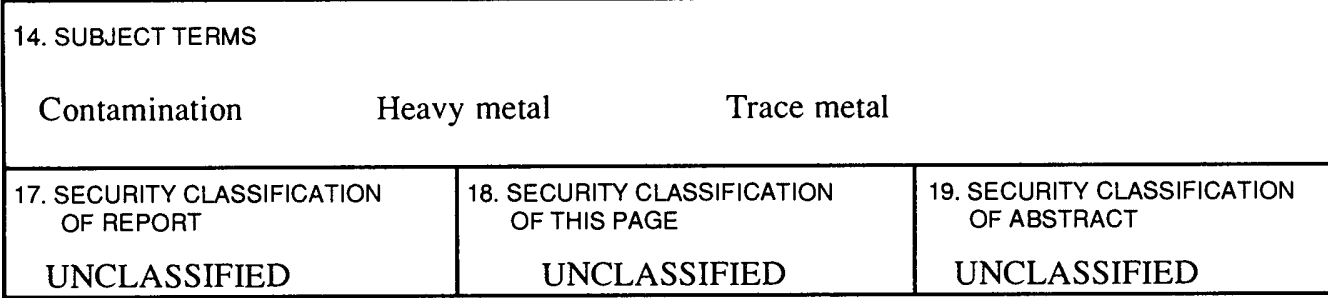

15. NUMBER OF PAGES 19

16. PRICE CODE 
Incomplete digestion and contamination occurred more frequently using hot-plate digestion. For two separate but identical microwave digestion treatments, the average coefficient of variability (CV) values of digestion replication means were $20.5 \%$ and $28.7 \%$, respectively. The analogous values for the block digestion and hot-plate methods were $39.2 \%$ and $69.5 \%$, respectively. The hot-plate digestion variability was significantly greater than either the block digestion or microwave methods. Microwave digestions provided markedly faster digestion times and often greater zinc release than other methods. Zinc release using microwave digestions was equal to or greater than that using other methods. This study demonstrated that regardless of digestion method, variability within a soil sample presents significant challenges, both in obtaining uniform analytical results and in interpretation. 